\title{
Macromolecular Synthesis Inhibitors Prevent Oxidative Stress- induced Apoptosis in Embryonic Cortical Neurons by Shunting Cysteine from Protein Synthesis to Glutathione
}

\author{
Rajiv R. Ratan, ${ }^{1,2,4}$ Timothy H. Murphy, ${ }^{2, a}$ and Jay M. Baraban ${ }^{2,3}$ \\ Departments of ${ }^{1}$ Neurology, ${ }^{2}$ Neuroscience, ${ }^{3}$ Psychiatry and Behavioral Science, and ${ }^{4}$ Rehabilitation Medicine, The Johns \\ Hopkins University School of Medicine, Baltimore, Maryland 21205
}

\begin{abstract}
Although macromolecular synthesis inhibitors have been demonstrated to prevent neuronal apoptosis in a number of paradigms, their mechanism of protection remains unclear. Recently, we found that neuronal death resulting from cystine deprivation, glutathione loss, and oxidative stress is apoptotic and is prevented by inhibitors of macromolecular synthesis. We now report that protection is associated with enhanced availability of acid-soluble cyst(e)ine and restoration of cellular glutathione levels. $\mathrm{N}$-acetylcysteine, an agent that delivers exogenous cysteine intracellularly and raises glutathione, is also protective, while buthionine sulfoximine, an inhibitor of glutathione synthesis, prevents protection by inhibitors of macromolecular synthesis. These results suggest that protection provided by these agents, in this paradigm, derives from shunting of the amino acid cysteine from global protein synthesis into the formation of the antioxidant glutathione.
\end{abstract}

[Key words: apoptosis, cycloheximide, glutathione, oxidative stress, glutamate, cortical neurons, cyst(e)ine]

Inhibitors of macromolecular synthesis have been shown to abrogate neuronal death induced by a broad range of stimuli, including nerve growth factor deprivation (Martin et al., 1988; Oppenheim et al., 1990; Scott and Davies, 1990; Mesner et al., 1992), hypoxia and hypoglycemia (Goto et al., 1990; Papas et al., 1992), MPTP (1-methyl-4-phenyl-1,2,3,6-tetrahydropyridine) (Di Pasquale et al., 1991), calcium channel antagonists (Koh and Cotman, 1992), and x-irradiation (Ferrer, 1992). In each of these paradigms (many of which demonstrate morphologic and/or biochemical features of apoptosis) protection by inhibitors of macromolecular synthesis has been interpreted as evidence for a gene-directed program of cell suicide (Martin et al., 1988; Oppenheim, 1991). In vertebrate systems, efforts to define a specific protein, or cascade of proteins, whose timely expression results in cell death have been inconclusive (Franklin and Johnson, 1992). Moreover, while protective effects of mac-

\footnotetext{
Received Sept. 10, 1993; revised Dec. 16, 1993; accepted Jan. 27, 1994.

This work was supported by an NRSA Neurorehabilitation Fellowship Institutional Training Grant 5T32HD07428 (R.R.R.), USPHS Grant DA-00266 and RSDA Grant MH-00926 (J.M.B.). We thank Darla Rodgers for excellent secretarial assistance, and Richard O'Brien and Jack Griffin for constructive comments on the manuscript.

- Present address: Kinsmen Laboratory for Neurolugical Research, University of British Columbia, Vancouver, BC 6VT1Z3 Canada.

Correspondence should be addressed to Rajiv Ratan, M.D., Ph.D., Johns Hopkins University, Department of Neuroscience, WBSB 908, 725 North Wolfe Street, Baltimore, MD 21205.

Copyright (C) 1994 Society for Neuroscience $0270-6474 / 94 / 144385-08 \$ 05.00 / 0$
}

romolecular synthesis inhibitors unrelated to specific "death" proteins have been proposed (Franklin and Johnson, 1992; Papas et al., 1992), plausible schemes have yet to be demonstrated.

We recently showed that degeneration of immature primary cortical neurons induced by continuous exposure to glutamate or homocysteate (IICA) for $24 \mathrm{hr}$ displays morphologic and biochemical features of apoptosis (Ratan et al., 1994). In this paradigm, the toxic effects of glutamate do not appear to result from receptor-mediated activation of transmembrane ion fluxes or phosphatidylinositol turnover (Murphy and Baraban, 1990), but rather result from glutamate's ability to inhibit competitively the uptake of the amino acid cystine at its plasma membrane transporter (Murphy et al., 1989, 1990). Inhibition of cystine uptake or removal of cystine from the bathing medium leads to depletion of the antioxidant glutathione and death due to oxidative stress. Apoptotic death due to glutathione depletion can be prevented not only by the antioxidants vitamin E (Murphy et al., 1990), idebenone, and butylated hydroxyanisole but also by inhibitors of macromolecular synthesis (Ratan et al., 1994).

Herein, we demonstrate that macromolecular synthesis inhibitors act by a novel mechanism of protection. Suppression of protein synthesis enhances availability of the amino acid cysteine, which can then be used to increase production of cellular antioxidants, such as glutathione. These observations suggest that macromolecular synthesis inhibitors may protect against cell death induced by oxidative stress by augmenting cellular antioxidant defenses.

\section{Materials and Methods}

Cell cultures were obtained from the cerebral cortex of fetal SpragueDawley rats (day 17 of gestation) as previously described (Murphy et al., 1990). All experiments were initiated $24-72 \mathrm{hr}$ after plating. These young cultures do not express significant receptor mediated responscs to glutamate and thus do not appear to be susceptible to excitotoxicity. For cystine deprivation-induced cytotoxicity studies, the cells were rinsed once with warm phosphate-buffered saline (PBS) and then switched to medium [Minimum Essential Medium (MEM; Advanced Biotechnologies) with $5.5 \mathrm{gm} /$ liter glucose, $5 \% \mathrm{FCS}, 2 \mathrm{~mm}$-glutamine, and 100 $\mu \mathrm{M}$ cystine containing the glutamate analog homocysteate $(0.25-10$ mм). Homocysteate was diluted from 100 -fold concentrated solutions that were adjusted to $\mathrm{pH} 7.5$. Media containing cycloheximide $(0.001-$ $10 \mu \mathrm{g} / \mathrm{ml})$, actinomycin-D $(2 \mu \mathrm{g} / \mathrm{ml})$, anisomycin $(0.005-0.5 \mu \mathrm{g} / \mathrm{ml})$, or idebenone $(3 \mu \mathrm{M})$ were made by diluting at least 1000 -fold concentrated solutions prepared in dimethyl sulfoxide (DMSO vehicle, $0.1 \% \mathrm{v} / \mathrm{v}$, had no protective or toxic effect by itself). Buthionine sulfoximine $(200 \mu \mathrm{M}$ to $1 \mathrm{mM})$ and $N$-acetylcysteine $(100 \mu \mathrm{M})$ were diluted from stock solutions that had been prepared in sterile water and adjusted to $\mathrm{pH} 7.5$ All pharmacologic agents were from Sigma unless otherwise specified.

Loss of membrane integrity is a late event in apoptotic death (Wyllie, 


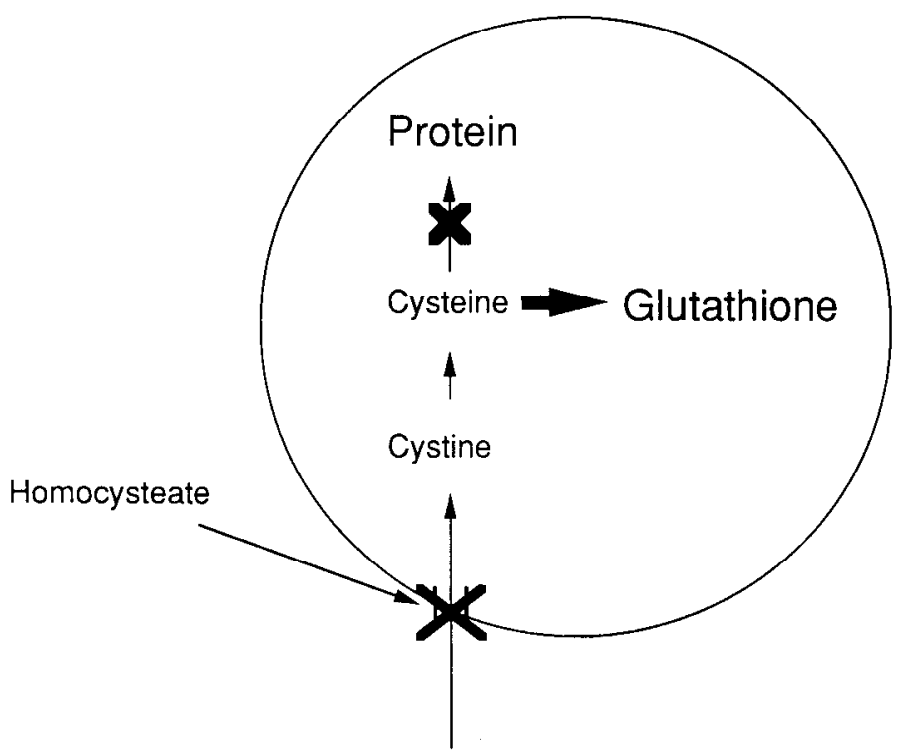

Cysteine $\longrightarrow$ Cystine

Figure 1. Diagram of proposed mechanism of protection by macromolecular synthesis inhibitors in preventing glutamate- or homocysteate-induced neuronal death. Many cells require exogenous cysteine because they are not capable of synthesizing it. However, cysteine, added to culture medium, or releascd from the cell, is unstable and rapidly auto-oxidized to cystine. Cystine crosses the cell membrane via a cystine/glutamate antiporter, a process driven by facilitated diffusion. Once inside the cell, cystine is rapidly reduced back to cysteine, where il can be utilized, primarily, for synthesizing protein and glutathione. Inhibition of transmembrane cystine transport in immature cortical neurons by glutamate analogs such as HCA, or low exogenous cystine, leads to a depletion of cysteine and consequently glutathione. Macromolecular synthesis inhibitors spare cysteine and allow it to be utilized for synthesis of glutathione and maintenance of cellular antioxidant potential.

1980). Cell death was quantitated by the release of the cytosolic enzyme lactate dehydrogenase (LDH) as previously described, 8-10 hr after the appearance of chromatin condensation and fragmentation typical of apoptosis ( $24 \mathrm{hr}$ after the onset of HCA exposure) (Ratan et al., 1994). Glia, which represent approximately $25 \%$ of cells in these primary cortical cultures, are spared under conditions of cystine deprivation that induce neuronal cell death (Murphy et al., 1990). Measurements of LDH relcasc, as a fraction of the total LDH in the culture, thus underestimate percentage of neuronal death.

Glutathione measurements. Total glutathione levels (GSH + GSSG) were measured by the method of Tietze (1969) as described in Murphy et al. (1989) with the following modifications. After $8-12 \mathrm{hr}$ of exposure to potential toxins \pm inhibitors, the cells were washed once with cold PBS. They were then lysed with $0.5 \%$ Triton X-100 in $0.1 \mathrm{M}$ potassium phosphate buffer, $\mathrm{pH} 7.0(500 \mu \mathrm{l}$ per $60 \mathrm{~mm}$ dish), and scraped off the bottom of the dish with a rubber policeman. The resulting lysate was divided in half for $\mathrm{LDH}$ and glutathione measurements. The half utilized for glutathione measurements was dissolved in an equal volume of $6 \%$ perchloric acid (PCA). The remaining steps of the glutathione assay were performed as previously described (Murphy et al., 1990). Glutathione is conventionally expressed as a function of total protein in cell extracts. In the present study, we normalized glutathione to LDH activity $\left(A_{340} / \mathrm{min}\right)$ in cell extracts rather than total protein, as the latter is affected by protein synthesis inhibitors and would falsely overestimate glutathione levels. The method of normalization was validated by the observation that $\mathrm{LDH}$ activities do not change at early time points $(<18$ hr of HCA exposure).

Single-cell assessment of glutathione levels was performed using the glutathione indicator dye monochlorobimane (BmCl; Molecular Probes) (Fernandez-Checa and Kaplowitz, 1990). For bimane fluorescence, cells were incubated for $10 \mathrm{~min}$ with $5 \mu \mathrm{M} \mathrm{BmCl}$ (dissolved in media) at $37^{\circ} \mathrm{C}$, rinsed gently with warm phosphate buffer, and placed in a buffered salt solution. Cells were excited at $380 \mathrm{~nm}$, and bimane fluorescence was observed using a $450 \mathrm{~nm}$ emission filter. To determine the specificity of fluorescence for glutathione, cells in parallel dishes were incubated with 2 mm diethyl maleate (DEM) for 15 min and rinsed thoroughly with warm PBS prior to $\mathrm{BmCl}$ loading. DEM is enzymatically conjugated to glutathione by glutathione-S transferase and thus acts to deplete glutathione (Bellomo et al., 1992).

${ }^{35} S$-cystine uptake studies. Radioactive uptake experiments were performed as described previously (Murphy et al., 1990) with the following modifications. Cultured cells plated in 6- or 12-well dishes were washed with $1 \mathrm{ml} /$ well of PBS and then incubated for $3 \mathrm{hr}$ at $37^{\circ} \mathrm{C}$ with $1 \mathrm{~mm}$ HCA with or without $10 \mu \mathrm{g} / \mathrm{ml}$ cycloheximide that had heen dissolved in MEM medium. Prior to labeling, the cells were rinsed once with PBS and the medium was replaced with $1 \mathrm{~mm} \mathrm{HCA} \pm 10 \mu \mathrm{g} / \mathrm{ml}$ cycloheximide dissolved in $1 \mathrm{ml}$ of a control salt solution, containing $120 \mathrm{~mm}$ $\mathrm{NaCl}, 5.4 \mathrm{~mm} \mathrm{KCl}, 1.8 \mathrm{~mm} \mathrm{CaCl}, 25 \mathrm{~mm}$ Tris hydrochloride $\mathrm{pH} 7.4$, 15 mм glucose, 2 mм L-glutamine, $1 \mu \mathrm{M}$ cystine, and 2 mM D-aspartate. D-Aspartate was added to inhibit uplake of radioactive cystine into glia via its low-affinity, high-capacity transporter (Murphy et al., 1990); 2 $\mu \mathrm{Ci}$ of ${ }^{35} \mathrm{~S}$-cystine $(686.1 \mathrm{Ci} / \mathrm{mmol}$; New England Nuclear) was then added to each well for $20 \mathrm{~min}$. In parallel, cells were labeled in the presence of an excess of cold cystine $(1 \mathrm{~mm})$ to determine nonspecific radioactive uptake. The labeling was stopped by three rapid washes with $2 \mathrm{ml}$ of ice-cold PBS supplemented with $1 \mathrm{mM} \mathrm{CaCl}_{2}$ and $1 \mathrm{mM} \mathrm{MgCl}_{2}$. Immediately after the washes, the cells were lysed with 3\% PCA, scraped, and transferred to Eppendorf tubes. The samples were spun for $10 \mathrm{~min}$ at $7400 \times g$ at $4^{\circ} \mathrm{C}$, and the radioactivity of an aliquot of the supernatant was determined by liquid scintillation counting as a measure of the acidsoluble ${ }^{35} \mathrm{~S}$-cyst(e)ine. The acid-precipitable pellet, containing the labeled, newly synthesized protein, was dissolved in $0.1 \mathrm{M} \mathrm{NaOH}$. The radioactivity in this $\mathrm{NaOH}$ solute was measured and the protein was determined by the bicinchoninic acid reagent (Pierce) method (Smith et al., 1985). In parallel experiments, treatment with $\mathrm{HCA} \pm$ cycloheximide $(10 \mu \mathrm{g} / \mathrm{ml})$ and labeling with $2 \mu \mathrm{Ci} / \mathrm{ml}$ of ${ }^{35} \mathrm{~S}$ were performed for a period of $3 \mathrm{~min}$, to determine the direct effects of cycloheximide on the initial rate of cystine uptake. Measurements of acid-soluble and acid-precipitable radioactivity were then performed as described above.

Statistics. Results are presented as mean \pm standard error of the mean for three to five experiments unless otherwise noted. Experimental groups with multiple treatments were analyzed hy analysis of variance.

\section{Results}

Glutathione levels after treatment with macromolecular synthesis inhibitors

In recent studies, we have found that macromolecular synthesis inhibitors block neuronal toxicity in immature primary cortical cultures induced by cystine deprivation and subsequent glutathione depletion (Ratan et al., 1994). In considering possible mechanisms mediating protection by these inhibitors, we noted that in addition to being a vital precursor for glutathione synthesis, intracellular cysteine is also utilized in protein synthesis. Therefore, we examined whether protection conferred by macromolecular synthesis inhibition could result from a redistribution of cysteine from protein synthesis into the formation of glutathione (Fig. 1). Unexpectedly, we found that cycloheximide and actinomycin-D increase glutathione (GSSG + GSH) in HCAtreated cultures (Table 1). The degree of elevation of glutathione by cycloheximide and actinomycin-D, respectively, correlates with their ability to protect neurons from cell death (Table 1). To ensure that decreases in glutathione levels do not reflect an alteration in cell number, glutathione measurements were performed 8-12 hr after the onset of HCA exposure (prior to any morphologic or biochemical indices of apoptosis or loss in membrane integrity). In this regard, LDH activities in cell extracts, which nave been shown to be proportional to cell number (Schnarr et al., 1979; Koh and Choi, 1987), were nearly identical ( $\leq 10 \%$ differences among treatment groups) at the time of glutathione assay.

Measurement of glutathione and cell viability as a function 
Table 1. Cycloheximide and actinomycin-D protection is associated with increases in total intracellular glutathione

\begin{tabular}{lll} 
Treatment & Glutathione $(\mu \mathrm{g})$ & $\begin{array}{l}\text { Cyto- } \\
\text { toxicity } \\
\text { (\% LDH } \\
\text { release) }\end{array}$ \\
\hline Control & $9.8 \pm 1.4 n=5$ & $13+2 \%$ \\
$1 \mathrm{~mm}$ homocysteate & $2.6 \pm 0.4 n=5^{*}$ & $69 \pm 6 \% *$ \\
$1 \mathrm{~mm}$ homocysteate $+\mathrm{chx}$ & $8.8 \pm 1.4 n=5$ & $12 \pm 3 \%$ \\
$1 \mathrm{~mm}$ homocysteate + act-D & $5.2 \pm 0.4 n=5^{*}$ & $32 \pm 5 \%^{*}$ \\
$1 \mathrm{~mm}$ homocysteate $+0.1 \%$ DMSO & $2.9 \pm 0.6 n=5^{*}$ & $69 \pm 9^{*}$
\end{tabular}

Cells were treated with $\mathrm{HCA} \pm$ potential inhibitors as described in Figure l. Total glutathione (GSSG + GSH) was measured as described in Materials and Methods and normalized to LDH activity of the same cell extracts. Measurements of glutathione were performed 8-12 $\mathrm{hr}$ after exposure to $\mathrm{HCA} \pm$ inhibitors, prior to morphologic or biochemical $(\leq 10 \%$ difference in LDH activity of cell extracts among treatment groups) evidence of cell death. In parallel cultures, cell death was measured by quantifying release of LDH after 22-24 hr. Values in each group represent mean \pm SEM for three to five different experiments. We did not observe an increase in glutathione in control cells treated with macromolecular synthesis inhibitors, suggesting that under these conditions intracellular cysteine content may not be rate limiting for glutathione synthesis (data not shown). chx, cycloheximide; act-D, actinomycin-D; DMSO, dimethyl sulfoxide.

* Statistical difference from control $(p<0.05)$.

of HCA concentration revealed a close correlation between total intracellular glutathione measured prior to cell death $(8-12 \mathrm{hr}$ after exposure to $\mathrm{HCA}$ ) and cell viability measured $22-24 \mathrm{hr}$ after the onset of HCA treatment (Fig. 2). These observations, along with the previous finding that vitamin E potently protects against toxicity from cystine deprivation but does not result in restoration of cellular glutathione, suggest that glutathione depletion is a cause, not a consequence, of cell injury (Murphy et al., 1989).

Total glutathione measurements reflect glutathione in both glia and neurons in these mixed cultures. Previous histochemical and biochemical studies have suggested that concentrations of total glutathione are low in neurons relative to glial cells in brain (Slivka, 1987) and in murine primary mixed cultures (Raps et al., 1989). Along with other studies (Murphy et al., 1989, 1990; Cho and Bannai, 1990; Kato et al., 1992), our data emphasize the importance of cystine transport to neuronal and glial glutathione homeostasis. To determine whether glutathione resides primarily in neurons or glia, we measured glutathione in mixed cultures in the presence of a selective inhibitor of glial cystine uptake, D-aspartate. Previous autoradiographic studies in mixed cultures revealed that the majority of ${ }^{35} \mathrm{~S}$-cystine uptake occurs in glia via a high-capacity, low-affinity, chloride-dependent cystine antiporter sensitive to glutamate. Blockade of this highcapacity transporter with $\mathrm{D}$-aspartate results in significant loss of autoradiographic labeling of glia (Murphy et al., 1990). D-Aspartate treatment ( $2 \mathrm{~mm}$ ) for $24 \mathrm{hr}$ in the present study reduces total glutathione by only $33 \%$ (in contrast to the $>70 \%$ reduction seen after $8-12 \mathrm{hr}$ in the presence of inhibitors of the chloride-dependent antiporter), suggesting a significant amount of the glutathione measured is derived from neurons. As was previously shown (Murphy et al., 1990), blockade of the glial transporter by $D$-aspartate did not result in neuronal death after $24 \mathrm{hr}$ (data not shown).

Additional evidence that the glutathione content of neurons is similar to that of glia in mixed cultures was obtained by labeling with the glutathione reporter monochlorobimane (Fig. $\left.3 A, A^{\prime}\right)$. The fluorescence signal in both neurons and glia was

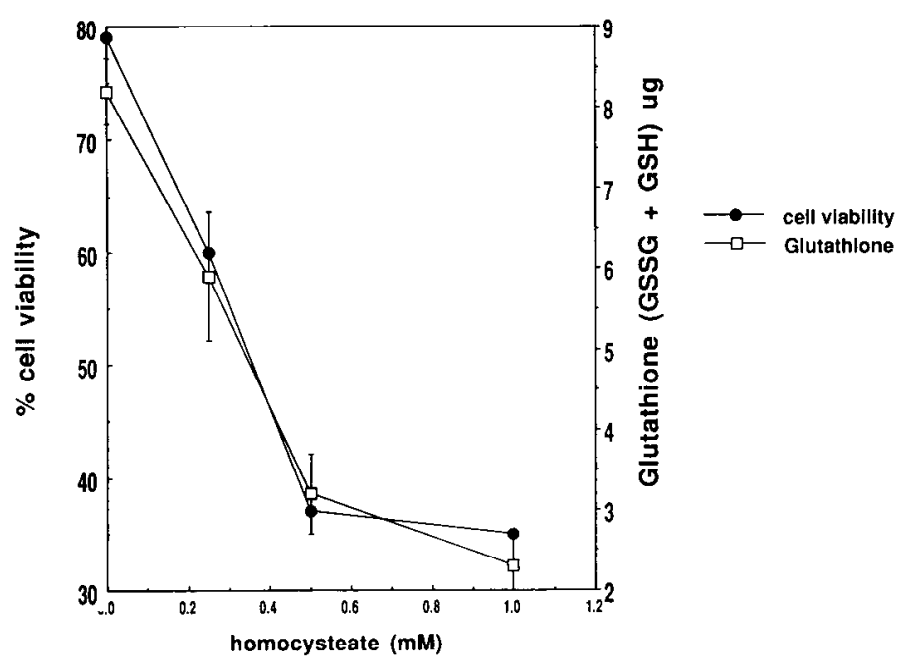

Figure 2. Total glutathione levels are closely correlated with cell survival. Total glutathione (GSSG $+\mathrm{GSH}) \mu \mathrm{g}$ (normalized to LDH activity of cell extracts; solid circles) was measured 8-12 hr after exposure to varying concentrations of HCA (0-1 mM) as described in Table 1. In parallel, percentage viability ( $100-\%$ LDH release; open squares) was measured 22-24 hr after exposure at varying concentrations of HCA (0-1 mM). Values for each group represent mean \pm SEM for three to five experiments performed in triplicate. SE bars for measurements of percentage cell viability are not shown, but represent less than $5 \%$ of the mean value for each concentration of HCA.

completely abolished by pretreatment with DEM, a glutathionedepleting agent (Fig. 3B, $B^{\prime}$ ).

\section{The effects of cycloheximide on radioactive cystine uptake in homocysteate-treated cultures}

To determine whether sufficient cyst(e)ine is shunted from protein synthesis to account for the observed rise in cellular glutathione after macromolecular synthesis inhibition, we measured uptake of radioactive cystine into the perchloric acid (PCA)soluble and PCA-precipitable (protein) fractions. Glutathione and its thiol precursors are acid soluble, while cysteine incorporated into protein is acid precipitable (Tietze, 1969).

$\mathrm{HCA}(1 \mathrm{~mm})$ reduced incorporation of radioactive cystine into the acid-soluble fractions of embryonic cortical cultures by $58 \pm 12 \%$ ( $p<0.05$; Fig. 4$)$, in agreement with the observed decrease in total glutathione in this treatment group. Incorporation of radioactive cystine into the acid-insoluble fraction (protein) was similarly decreased $(53 \pm 9 \%, p<0.05$; Fig. 4). Treatment with $10 \mu \mathrm{g} / \mathrm{ml}$ of cycloheximide for $3 \mathrm{hr}$ in the presence of HCA reduced incorporation of cystine into protein by greater than $90 \%$ of controls. However, cystine labeling in the acid-soluble fraction was nearly equivalent to controls (Fig. 4), in agreement with our findings of preserved glutathione in cells treated with HCA and cycloheximide together.

To determine whether increases in soluble cystine labeling reflect a direct effect of cycloheximide on cystine transport, cells exposed to HCA for $2 \mathrm{hr}$ were labeled with radioactive cystine in the presence and absence of cycloheximide for $3 \mathrm{~min}$ in addition to $20 \mathrm{~min}$. Although incorporation of radioactive cystine into protein after $3 \mathrm{~min}$ is decreased by greater than $90 \%$ in cycloheximide-treated cells, cycloheximide did not increase total cellular uptake of radioactive cystine at $3 \mathrm{~min}$ (data not shown) or 20 min of labeling (Fig. 4). We conclude that cycloheximide does not directly affect cystine transport, but rather 
Figure 3. Staining with the glutathione specific reporter monochlorobimane demonstrates that glutathione is present in neurons and glia in mixed cortical cultures. Forty-eight hours after plating, cultured neurons were loaded with $5 \mu \mathrm{M}$ monochlorobimane (dissolved in media) for $10 \mathrm{~min}$ at $37^{\circ} \mathrm{C}$. Monochlorobimane becomes fluorescent only after enzymatic conjugation to reduced glutathione. Cultures were then rinsed gently in warm PBS and transferred to a buffered salt solution. $A$, Cultured cells visualized under Hoffman microscopy. $A^{\prime}$, Cells depicted in $A$ loaded with monochlorbimane and visualized under florescence microscopy. Arrowheads ( $A$ and $A^{\prime}$ ) point to cluster of cells with the morphology of neurons. Asterisks ( $A$ and $A^{\prime}$ ) refer to flat, large cell typical of a glial cell. Note that all the cells in the field are labeled. To determine the specificity of the fluorescent signal for reduced glutathione, cultures depicted under Hoffman microscopy in $B$ were treated with diethyl maleate ( $2 \mathrm{~mm}$ ) for $15 \mathrm{~min}$ prior to labeling with monochlorobimane. Diethyl maleate depletes glutathione by conjugating to it, a process catalyzed by the enzyme glutathione transferase. $B^{\prime}$, Monochlorobimane fluorescence of cells depicted in $B$ after depletion of glutathione. Note the absence of labeling in any of the cells in the field.
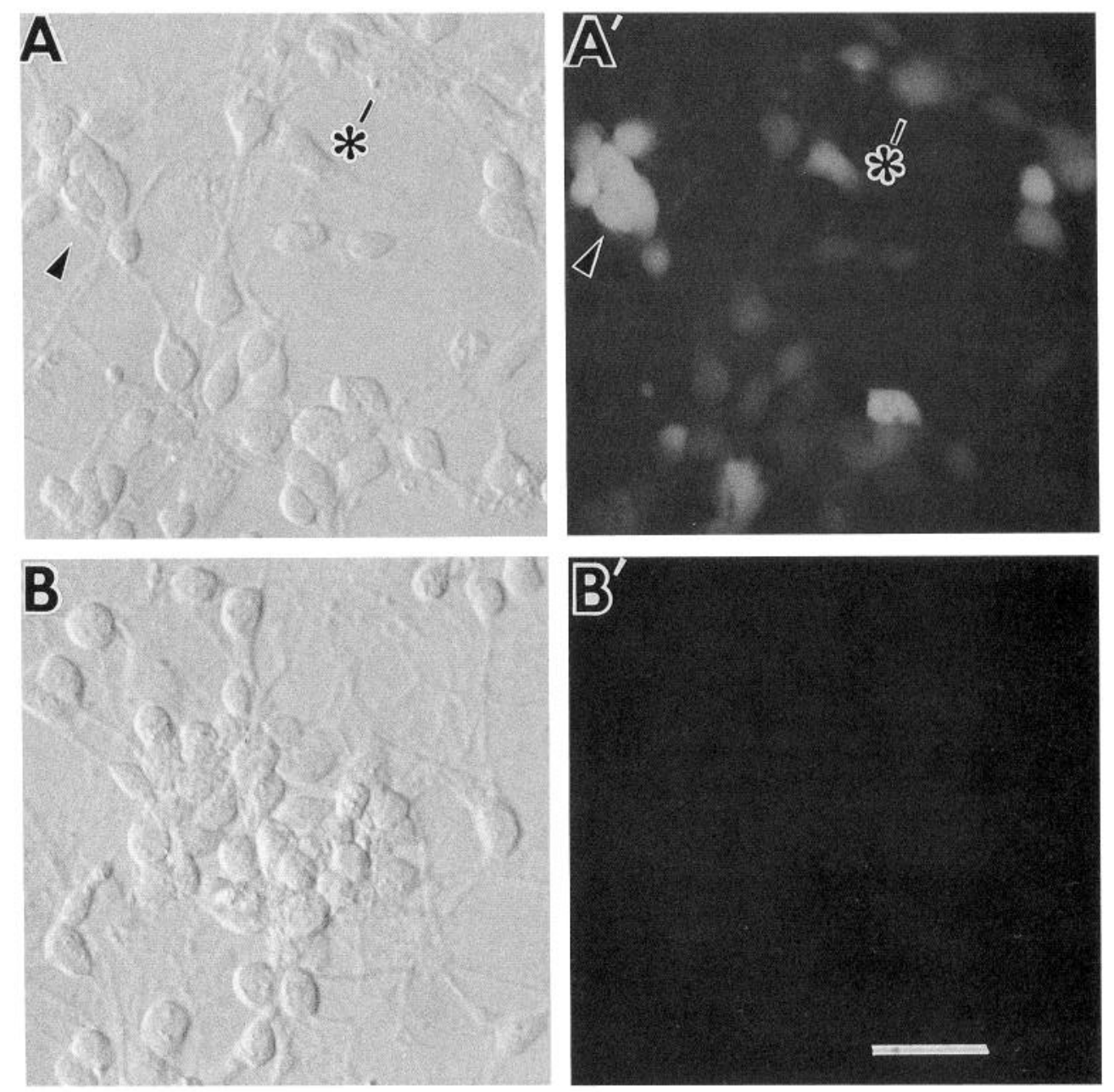

influences soluble radioactive cystine levels by accumulation of precursors liberated by inhibition of protein synthesis. While the most likely candidate for the increase in soluble radioactivity is redistributed cysteine, changes may also result from an increase in intracellular glutamate, which by facilitated diffusion out of the cell at the cystine/glutamate antiporter, would act to overcome HCA inhibition and drive cystine into the cell (Bannai and Ishii, 1988). While our experiments do not allow us to rule out other possibilities related to inhibiting synthesis of specific proteins, such as glutathione-degrading enzymes, they do suggest that elevations in glutathione can account for the observed protection of macromolecular synthesis inhibitors.

\section{Potency and specificity of protein synthesis inhibitors}

To determine the degree of protein synthesis inhibition required for protection, we measured cell viability in the presence of 1 mM HCA as a function of cycloheximide concentration. We found cells could be maximally protected against HCA-induced degeneration with concentrations of cycloheximide as low as $100 \mathrm{ng} / \mathrm{ml}$ (Fig. 5a). This concentration of cycloheximide only inhibited protein synthesis by about half, but was sufficient to restore glutathione to control levels $[9.8 \pm 0.6 \mu \mathrm{g}$ (normalized to LDH activity; see Materials and Methods), $1 \mathrm{~mm} \mathrm{HCA} \mathrm{+}$ $100 \mathrm{gm} / \mathrm{ml}$ cycloheximide; versus controls, $10.6 \pm 0.5 \mu \mathrm{g}$ (normalized to LDH activity); $p>0.05$ ].

Anisomycin, another inhibitor of protein synthesis, also pre- vented cell death induced by $1 \mathrm{~mm}$ HCA (Fig. $5 b$ ). Because anisomycin acts through a different mechanism to inhibit protein synthesis, it is likely that the effects of cycloheximide and anisomycin derive from protein synthesis inhibition rather than a nonspecific mechanism. In support of this conclusion, anisomycin was found to increase PCA-soluble ${ }^{35} \mathrm{~S}$-cystine incorporation and total glutathione levels to the same extent as cycloheximide (data not shown).

\section{$\mathrm{N}$-acetylcysteine protects against glutamate analog toxicity}

If the protective actions of cycloheximide, anisomycin, and actinomycin-D result from their ability to replenish cellular cysteine depleted by HCA-induced blockade of cystine uptake, then agents known to deliver cysteine into the cell should also be protective. $\mathrm{N}$-acetylcysteine has been used as an antioxidant in a variety of systems. It decreases membrane damage by superoxide-generating systems in porcine aortic endothelial cells (Junod et al., 1987), diminishes endotoxin-induced lung damage in sheep (Gernard et al., 1984), and protects animals against acetaminophen hepatotoxicity (Miners et al., 1984). The protective effects of $\mathrm{N}$-acetylcysteine appear to result from its ability to increase cellular cysteine and glutathione and/or scavenge oxidant species (Aruoma et al., 1989). $\mathrm{N}$-acetylcysteine has been shown to increase intracellular cysteine in fibroblasts in the presence of inhibitors of the cystine/glutamate antiporter such as glutamate or HCA (Issels et al., 1987). Consistent with these 


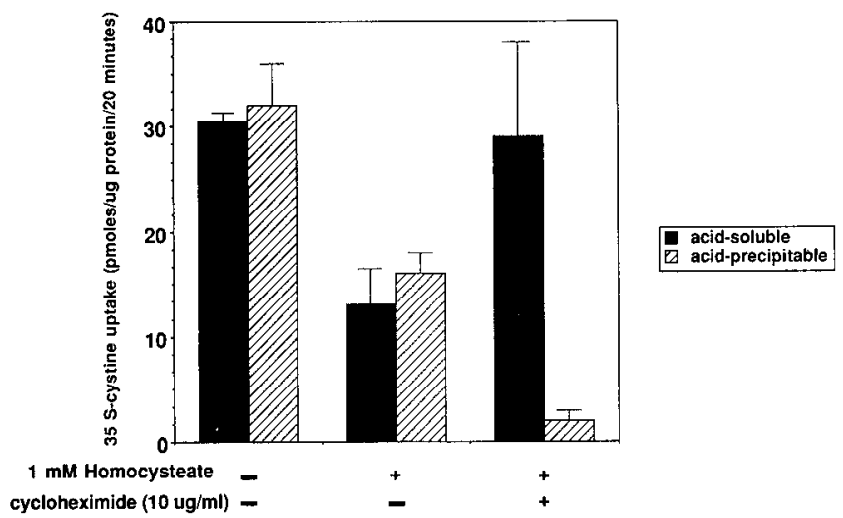

Figure 4. Cycloheximide increases acid-soluble $\mathrm{L}^{-35} \mathrm{~S}$-cystine in cultures exposed to homocysteate. Cultures were exposed to the designated treatments for $3 \mathrm{hr}$ at $37^{\circ} \mathrm{C}$. They were then labeled with L- ${ }^{35} \mathrm{~S}$-cystine for $20 \mathrm{~min}$ as described in Materials and Methods. The labeling was stopped by three rapid cold washes. The cells were resuspended in 3\% PCA and separated into acid-soluble and acid-precipitable fractions by centrifugation. The former fraction represents nonprotein thiols such as glutathione and the acid-precipitable fraction represents labeled, newly synthesized protein. In each column, the left bar (solid) indicates acid-soluble radioactivity and right bar (stippled) indicates acid-precipitable radioactivity. Uptake is expressed on the $y$-axis as picomoles of $\mathrm{L}-{ }^{35} \mathrm{~S}$-cystine/microgram of protein $/ 20 \mathrm{~min}$ of labeling. Asterisks denote statistical difference from control $(p<0.05)$.

reports, we found that $100 \mu \mathrm{M} N$-acetylcysteine completely protected embryonic cortical neurons from HCA toxicity (Fig. $6 a$ ). This protection was associated with restoration of glutathione above control values [ $1 \mathrm{mM} \mathrm{HCA}+100 \mu \mathrm{M} N$-acetylcysteine, $15.4 \pm 1.2 \mu \mathrm{g}$ glutathione (normalized to $\mathrm{LDH}$ activity), vs control, $10.8 \pm 0.5 \mu \mathrm{g}$ glutathione (normalized to $\mathrm{LDH}$ activity); $p<0.05]$.

\section{Cycloheximide protection is prevented in the presence of} buthionine sulfoximine, an inhibitor of glutathione synthesis

To determine if increases in glutathione observed in HCA-treated cultures exposed to cycloheximide are necessary for the survival promoting effects of these agents, we assessed the effects of buthionine sulfoximine (BSO). BSO is an irreversible inhibitor of $\gamma$-glutamylcysteine synthetase, the enzyme responsible for covalently linking glutamate and cysteine in the first step of glutathione synthesis (Griffith and Meister, 1979). It has been shown to cause a time-dependent decrease in glutathione in a variety of cell types (Meister, 1983). While concentrations of BSO above $500 \mu \mathrm{M}$ are lethal to immature cortical neurons (data not shown), $200 \mu \mathrm{M}$ BSO depletes cellular glutathione, but does not result in significant cell death after $24 \mathrm{hr}$ (Fig. 6b). Differences in viability in BSO $(200 \mu \mathrm{M})$ and HCA $(1 \mathrm{~mm})$ treated cultures, which deplete glutathione equally, may relate to HCA's ability to deplete cyst(e)ine as well as glutathione. Although it is a less efficient antioxidant than glutathione, cysteine can function to maintain the antioxidant potential of the cell by direct reduction of free radicals (Tsen and Tappel, 1958; Meister and Anderson, 1983; Newton and Fahey, 1990) as well as by acting as a precursor for cysteine-rich, antioxidant proteins such as metallothionein (Hidalgo, 1990).

Incubation of immature cortical neurons with HCA and cycloheximide, in the presence of $200 \mu \mathrm{M}$ BSO, prevented cycloheximide protection (Fig. $6 b$ ). In this setting, BSO prevents the preservation of glutathione observed with cycloheximide (44 \pm $5 \%$ of controls, $n=6 ; p<0.05$ by two-tailed $t$ test). BSOinduced toxicity in the presence of cycloheximide could be prevented by coadministration of the antioxidant idebenone $(3 \mu \mathrm{M})$ (Fig. 6b). Taken together, these results suggest that increases in
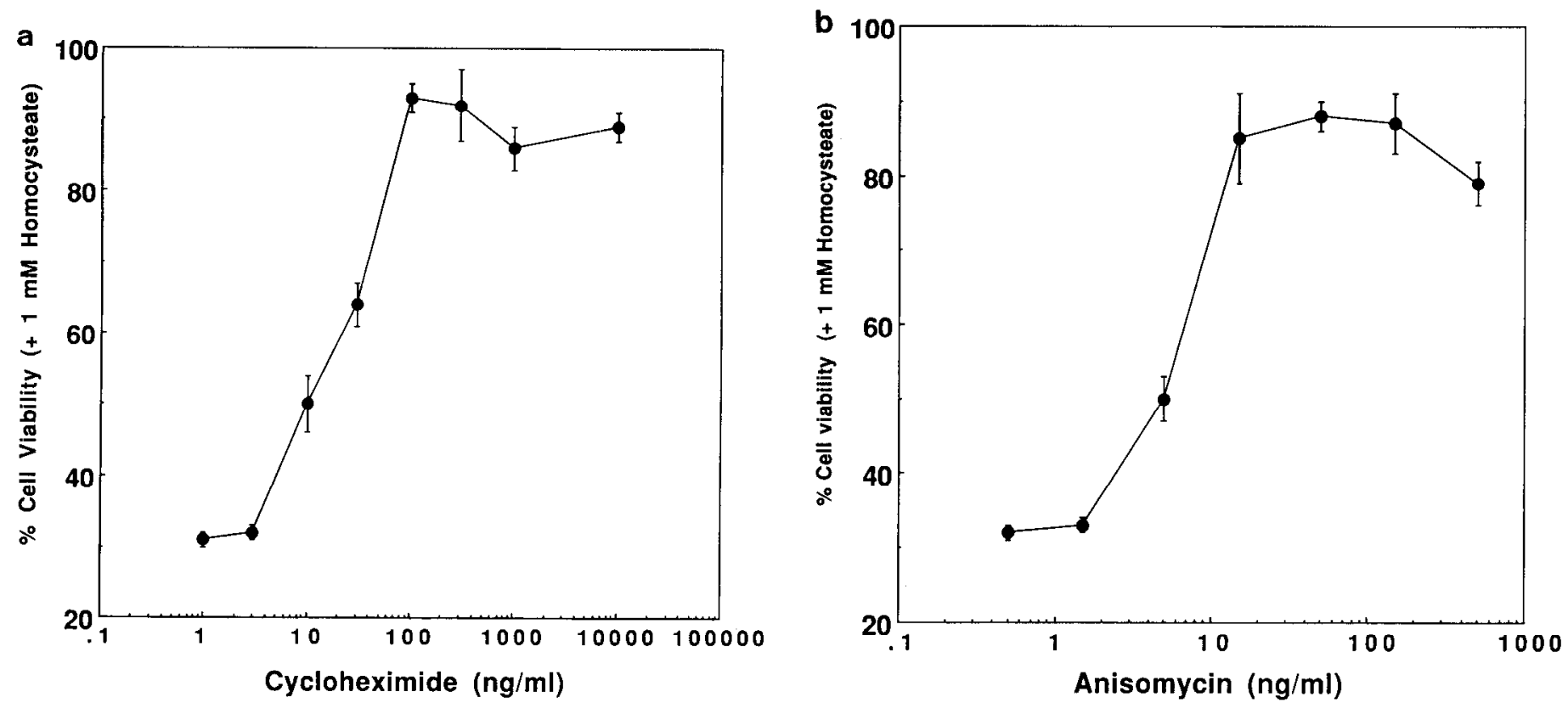

Figure 5. Concentration-response of cycloheximide and anisomycin on survival of cultured cortical neurons treated with homocysteate (1 mm). $a$, Cultures were exposed to $1 \mathrm{~mm} \mathrm{HCA}$ as described in Figure 1 with varying concentrations of cycloheximide. Percentage cell viability (solid circles) was determined by subtracting percentage of total LDH released during the experimental period from 100 . Results are expressed as means $\pm \mathrm{SEM}$ for at least three wells. $b$. Cultures exposed to $1 \mathrm{mM} \mathrm{HCA}$ as described in Figure 1 with varying concentrations of anisomycin. Results are expressed as means \pm SEM of percentage viability (as described for Fig. $6 a$ ) for at least three wells. 


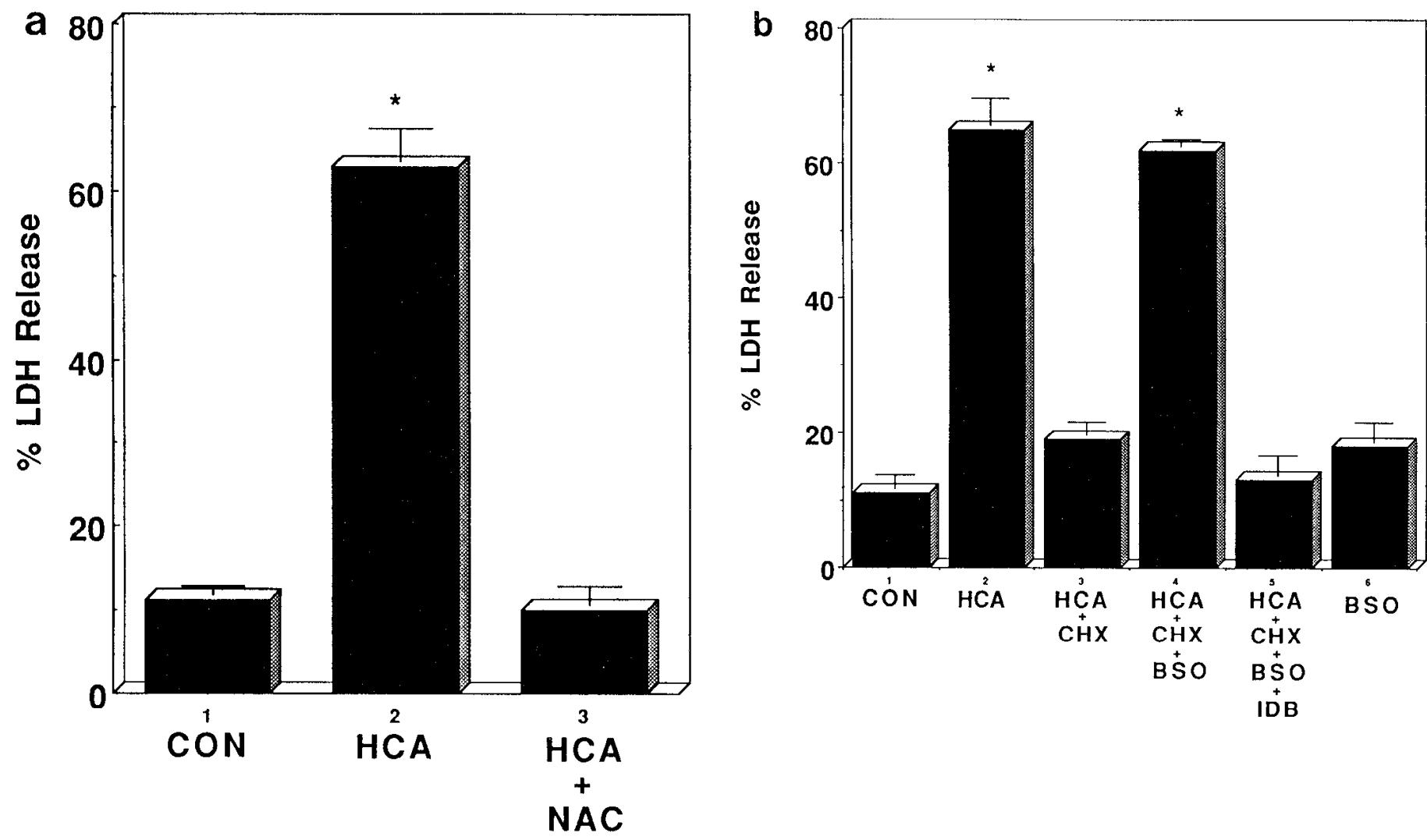

Figure 6. a, Effect of $N$-acetylcysteine $(100 \mu \mathrm{M})$ on LDH release caused by $24 \mathrm{hr}$ of exposure to HCA (1 mM). From 24 to $72 \mathrm{hr}$ after plating, cultures were treated with $\mathrm{HCA} \pm N$-acetylcysteine as in Figure 1 for $24 \mathrm{hr} . b$, Effect of buthionine sulfoximine $(B S O ; 200 \mu \mathrm{M})$ on cycloheximide

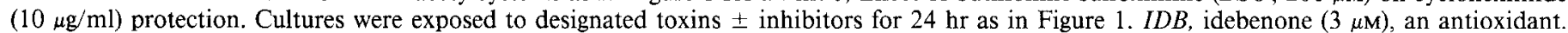
Each bar represents mean \pm SEM for three to five experiments performed in triplicate. Asterisk denotes statistical difference from control $(p<$ $0.05)$.

glutathione are necessary for cycloheximide protection against HCA toxicity.

\section{Discussion}

In a previous study, we demonstrated that delayed neuronal degeneration in an in vitro model of oxidative stress is apoptotic and can be prevented by macromolecular synthesis inhibitors (Ratan et al., 1994). We now provide evidence for a novel mechanism of protection by these agents that includes enhanced availability of nonprotein thiols and preservation of total levels of glutathione, thus preventing the adverse metabolic consequences of cystine uptake blockade (Table 1, Fig. 4). Similar preservation of cellular glutathione and cell viability in HCAtreated cultures occurs in the presence of $N$-acetylcysteine (Fig. $6 a$; see also Results). Taken together, these data suggest that maintenance of glutathione homeostasis is sufficient for cell survival in the presence of cystine deprivation in immature embryonic cortical neurons. Additionally, protection conferred by cycloheximide can be prevented by a specific inhibitor of glutathione synthesis, BSO (Meister, 1988), suggesting that formation of glutathione, in this paradigm, is necessary to manifest the survival-promoting effects of cycloheximide (Fig. 6b). BSO appears to reverse the antioxidant effects of cycloheximide, rather than inducing cell death by a distinct mechanism, as coadministration of the antioxidant idebenone with BSO, cycloheximide, and HCA prevented neuronal death (Fig. $6 b$ ).

Glutathione ( $\gamma$-glutamyl-L-cysteinylglycine) is a tripeptide that is widely distributed within peripheral and brain tissues (Meister and Anderson, 1983; Kudo et al., 1990). It is present in brain at concentrations of approximately 2 mм (Slivka et al., 1987), and the majority $(>99 \%)$ is enzymatically maintained in the reduced form (GSH). GSH is involved in protection against oxidative damage as well as detoxification of xenobiotics. It is capable of preserving cell integrity by reducing intracellular peroxides and free radicals, as well as by maintaining protein disulfide bonds in the reduced state (Orlowski and Karkowsky, 1976; Kosower and Kosower, 1978; Mitchell and Russo, 1987). The ability of macromolecular synthesis inhibitors to elevate cellular glutathione suggests that the protective actions of these agents in other systems may derive from their ability to enhance the antioxidant potential of the cell. Indeed, cycloheximide has been protective in a number of systems where free radical injury is believed to occur. Macromolecular synthesis inhibition spares granule cells from MPTP toxicity (DiPasquale et al., 1991). Such toxicity has been attributed to reactive oxygen species formed as a result of blockade of mitochondrial complex I by MPP+, a metabolite of MPTP (Hasegawa et al., 1990). Protein synthesis inhibitors have also been shown to reduce cortical neuronal death in vivo after x-irradiation (Ferrer, 1992). The lethal effects of ionizing radiation are believed to mediated, in part, through generation of free radicals (Mitchell and Russo, 1987). Modulation of glutathione levels influences both MPTP toxicity (Weiner et al., 1988; Adams et al., 1989) and radiation damage (Mitchell and Russo, 1987; Kuo et al., 1993), suggesting that the protective effects of macromolecular synthesis inhibition in 
these situations may derive from elevations of cellular glutathione.

Recent studies have elucidated an antioxidant role for the proto-oncogene $b c l-2$ in apoptosis and necrosis (Hockenbery et al., 1993; Kane et al., 1993). Together with the results presented here, these data are consistent with a role for free radicals in a final common pathway of cell death. Indeed, previous studies have shown that oxidative stress can induce apoptosis in nonneural cells (Lennon et al., 1991; Hockenberry et al., 1993; Sandstrom and Buttke, 1993) and neural cells (Ratan et al., 1994). One of these studies demonstrated that low levels of oxidative stress induce apoptosis, while at higher levels necrosis occurs (Lennon et al., 1991). This observation may reconcile our results with the previously held view that ischemia-induced oxidative stress in neurons reesults in necrosis (Deshpande et al., 1992).

Rates of protein synthesis have been shown to decrease as a consequence of insults such as trauma (Steward, 1986), excitotoxins (Orrego and Lipmann, 1967; Vornov and Coyle, 1991), hypoxia (Bodsch et al., 1986), serum deprivation (Montine and Henshaw, 1989), viral infection (Huang and Schneider, 1990), and heat shock (Duncan and Hershey, 1984). The onset of protein synthesis inhibition correlates with other signs of toxicity and has therefore becn interpretcd as a marker of cell stress and impending degeneration (Lipton and Heimbach, 1977; Thilman et al., 1986; Dwyer et al., 1987; Hovda et al., 1992). The present results suggest that cessation of protein synthesis under conditions of cell stress may reflect endogenous compensatory mechanisms engaged to delay or prevent incipient cell death. Specifically, liberation of amino acids such as cysteine may provide needed precursors to sustain cell defenses (Fig. 4). This observation raises the intriguing possibility that hormonal or pharmacologic agents capable of reversibly inhibiting protein synthesis could be utilized in proximity to an insult to mitigate neuronal damage. The additional finding in the present study that $N$-acetylcysteine is as effective a neuroprotectant as macromolecular synthesis inhibitors suggests that intracellular delivery of amino acid analogs may be as viable a therapeutic strategy as protein synthesis inhibition.

In summary, we have demonstrated that apoptosis induced by oxidative stress in primary cortical neurons can be prevented by inhibitors of transcription and translation (Ratan et al., 1994). The cytoprotective effects of these agents, in this paradigm, derive from their ability to preserve cellular antioxidant potential through elevations in glutathione. Preservation of glutathione may result simply from redistribution of the amino acid cysteine released by global protein synthesis inhibition, and may not involve the inhibition of specific "death" proteins. Additional studies are needed to determine whether macromolecular synthesis inhibitors prevent cell death in other paradigms by increasing glutathione.

\section{References}

Adams JD, Klaidman LK, Odunze IN (1989) Oxidative effects of MPTP in the midbrain. Res Commun Substance Abuse 10:169-180.

Aruoma OI, Halliwell B, Hoey BM, Butler J (1989) The antioxidant action of $\mathrm{N}$-acetylcysteine: its reaction with hydrogen peroxide, hydroxyl radical, superoxide, and hypochlorous acid. Free Radical Biol Med 6:593-597.

Bannai S, Ishii T (1988) A novel function of glutamine in cell culture: utilization of glutamine for the uptake of cystine in human fibroblasts. J Cell Physiol 137:360-366.
Bellomo G, Varietti M, Stivala L, Mirabelli F, Richclmi P, Orrenius S (1992) Demonstration of nuclear compartmentalization of glutathione in hepatocytes. Proc Natl Acad Sci USA 89:4412-4416.

Bodsch W, Barbier A, Oehmichen M, Grosse-Ophoff B, Hossman KA (1986) Recovery of monkey brain after prolonged ischemia. II. Protein synthesis and morphological alterations. J Cereb Blood Flow Metab 6:22-33.

Cho Y, Bannai S (1990) Uptake of glutamate and cystine in C-6 glioma cells and in cultured astrocytes. J Neurochem 55:2091-2097.

Deshpande J, Bergstedt K, LindenT, Kalimo H, Wieloch T (1992) Ultrastructural changes in the hippocampal CAl region following transient cerebral ischemia: evidence against programmed cell death. Exp Brain Res 57:91-105.

Di Monte D, Bellomo G, Thor H, Nicotera P, Orrenius S (1984) Alterations in intracellular thiol homeostasis during metabolism of menadione in isolated rat hepatocytes. Arch Biochem Biophys 235:334342.

Dipasquale B, Marini AM, Youle RJ (1991) Apoptosis and DNA degradation induced by 1-methyl-4-phenylpyridinium in neurons. Biochem Biophys Res Commun 181:1442-1448.

Duncan R, Hershey J (1984) Heat shock-induced translational alterations in Hela cells. J Biol Chem 259:11882-11889.

Dwyer BE, Nishimura RN, Powell CL, Mailhcau SL (1987) Focal protein synthesis inhibition in a model of neonatal hypoxic-ischemic brain injury. Exp Neurol 95:277-289.

Fernandez-Checa JC, Kaplowitz N (1990) The use of monochlorobimane to determine hepatic GSH levels and synthesis. Anal Biochem 190:212-219.

Ferrer I (1992) The effect of cycloheximide on natural and x-rayinduced cell death in the developing cerebral cortex. Brain Res 588: 351-357.

Franklin JL, Johnson E (1992) Suppression of programmed neuronal death by sustained elevation of cytoplasmic calcium. Trends Neurosci 15:501-508.

Gernard GR, Lucht WD, Niedermeyer ME, Snapper JR, Ogletree ML, Brigham KL (1984) Effect of $N$-acetylcysteine on the pulmonary response to endotoxin in the awake sheep and upon in vitro granulocyte function. J Clin Invest 73:1772-1784.

Goto K, Atsushi I, Sekiguchi K, Iizuka S, Sugimoto A, Yuzurihara M, Aburada M, Hosoya E, Kogure K (1990) Effects of cycloheximide on delayed neuronal death in rat hippocampus. Brain Res 534:299_ 302.

Griffith OW, Meister A (1979) Potent and specific inhibition of glutathione synthesis by buthionine sulfoximine $(S$ - $n$-butyl homocysteine sulfoximine). J Biol Chem 254:7558-7560.

Hasegawa E, Takeshige K, Oishi T, Murai Y, Minakami S (1990) 1-Methyl-4-phenylpiridinium (MPP+) induces NADH-dependent superoxide formation and enhances NADH-dependent lipid peroxidation in bovine heart submitochondrial particles. Biochem Biophys Res Commun 170:1049-1055.

Hidalgo J, Garvey JS, Armario A (1990) On the metallothionein, glutathione and cysteine relationship in rat liver. J Pharmacol Exp Ther 255:554-564.

Hockenbery DM, Oltivai ZN, Yin XM, Milliman CL, Korsmeyer SJ (1993) Bcl-2 functions in an anti-oxidant pathway to prevent apoptusis. Cell 75:241-251.

Hovda DA, Becker DP, Katayama Y (1992) Secondary injury and acidosis. J Neurotrauma 9:S47-S60.

Huang J, Schneider R (1990) Adenovirus inhibition of cellular protein synthesis is prevented by the drug 2-aminopurine. Proc Natl Acad Sci ISSA 87:7115-7119.

Issels RD, Nagele A, Eckert K-G, Wilmanns W (1988) Promotion of cystine uptake and its utilization for glutathione biosynthesis induced by cysteamine and $N$-acetylcysteine. Biochem Pharmacol 37:881888.

Junod AF, Jornot L, Grichting G (1987) Comparative study on the seleniuml- and $\mathrm{N}$-acetylcysteine-related effects on the toxic actions of hyperoxia, paraquat and the enzyme reaction hypoxanthine-xanthine oxidase in cultured endothelial cells. Agents Actions 22:177-183.

Kane DJ, Saratian TA, Anton R, Hahn H, Butler Gralla E, Seleverstone Valentine J, Ord T, Bredesen DE (1993) Bcl-2 inhibition of neural death: decreased generation of reactive oxygen species. Science 262 : 1274-1277.

Kato S, Negishi K, Mawatari K, Kuo CH (1992) A mechanism for 
glutamate toxicity in C6 glioma cells involving inhibition of cystine uptake leading to glutathione depletion. Neuroscience 48:903-914.

Koh J, Choi DW (1987) Quantitative determinants of glutamate mediated cortical neuronal injury in cell culture by lactate dehydrogenase efflux assay. J Neurosci Methods 20:83-90.

Koh J, Cotman C (1992) Programmed cell death: its possible contribution to neurotoxicity mediated by calcium channel antagonists. Brain Res 587:233-240.

Kosower NS, Kosower EM (1978) The glutathione status of cells. Int Rev Cytol 54:109-160.

Kudo H, Kokunai T, Kondoh T, Tamaki N, Matsumoto S (1990) Quantitative analysis of glutathione in rat central nervous system: comparison of GSH in infant brain with that in adult brain. Brain Res 511:326-328.

Kuo SS, Saad AH, Koong AC, Hahn GM, Giaccia AJ (1993) Potassium-channel activation in response to low doses of gamma-irradiation involves reactive oxygen intermediates in nonexcitatory cells. Proc Natl Acad Sci USA 90:908-912.

Lennon SV, Martin SJ, Cotten TG (1991) Dose-dependent induction of apoptosis in human tumor cells by widely diverging stimuli. Cell Prolif 24:203-214.

Lipton P, Heimbach CJ (1977) The effect of extracellular potassium concentration on protein synthesis in guinea-pig hippocampal slices. J Neurochem 28:1347-1354.

Martin DP, Schmidt RE, DiStefano PS, Lowry OH, Carter JG, Johnson EM Jr (1988) Inhibitors of protein synthesis and RNA synthesis prevent neuronal death caused by nerve growth factor deprivation. J Cell Biol 106:829-844.

Meister A (1988) Selective modification of glutathione metabolism. Science 220:472-477.

Meister A, Anderson ME (1983) Glutathione. Annu Rev Biochem 52: 711-760.

Mesner PW, Winters TR, Green SH (1992) Nerve growth factor withdrawal-induced cell death in neuronal $\mathrm{PC} 12$ cells resembles that in sympathetic neurons. J Cell Biol 119:1669-1680.

Miners JO, Drew R, Birkett DJ (1984) Mechanism of action of paracetamol protective agents in mice in vivo. Biochem Pharmacol 33: 2995-3000.

Mitchell JB, Russo A (1987) The role of glutathione in radiation and drug induced cytotoxicity. Br J Cancer 55:96-104.

Montine KS, Henshaw EC (1989) Serum growth factors cause rapid stimulation of protein synthesis and dephosphorylation of eIF-2 in serum deprived Ehrlich cells. Biochim Biophys Acta 1014:282-288.

Murphy TH, Baraban JM (1990) Glutamate toxicity in immature cortical neurons precedes development of glutamate receptor currents. Dev Brain Res 57:146-150.

Murphy TH, Miyamoto M, Sastre A, Schnaar RL, Coyle JT (1989) Glutamate toxicity in a neuronal cell line involves inhibition of cystine transport leading to oxidative stress. Neuron 2:1547-1558.

Murphy TH, Schnaar RL, Coyle JT (1990) Immature cortical neurons are uniquely sensitive to glutamate toxicity by inhibition of cystine uptake. FASEB J 4:1624-1633.

Newton GL, Fahey RC (1990) Glutathione in prokaryotes. In: Glutathione metabolism and physiological functions (Vina J, ed), pp 6977. Boca Raton, FL: CRC.

Oppenheim RW (1991) Cell death during development of the nervous system. Annu Rev Neurosci 14:453-501.
Oppenheim RW, Prevette D, Tytell M, Homma S (1990) Naturally occurring and induced neuronal death in the chick embryo in vivo requires protein and RNA synthesis: evidence for the role of cell death genes. Dev Biol 138:104-113.

Orlowski M, Karkowsky A (1976) Glutathione metabolism and some possible functions of glutathione in the nervous system. Int Rev Neurobiol 19:75-121.

Orrego F, Lipmann F (1967) Protein synthesis in brain slices: effects of electrical stimulation and acidic amino acids. J Biol Chem 242: 665-671.

Papas S, Crepel V, Hasboun D, Jorquera I, Chinestra P, Ben-Ari Y (1992) Cycloheximide reduces the effects of anoxic insult in vivo and in vitro. Eur J Neurosci 4:758-765.

Pellmar TC, Roney D, Lepinski DL (1992) Role of glutathione in repair of free radical damage in hippocampus in vitro. Brain Res 583: 194-200.

Raps SP, Lai JCK, Hertz L, Cooper AJL (1989) Glutathione is present in high concentrations in cultured astrocytes but not in cultured neurons. Brain Res 493:398-401.

Ratan RR, Murphy TH, Baraban JM (1994) Oxidative stress induces apoptosis in embryonic cortical neurons. J Neurochem 62:376-379.

Sandstrom PA, Buttke TM (1993) Autocrine production of extracellular catalase prevents apoptosis of the human CEM T-cell line in serum free medium. Proc Natl Acad Sci USA 90:4708-4712.

Schnaar RL, Weiger PH, Kuhlenschmidt MS, Lee YC, Roseman S (1978) Adhesion of chicken hepatocytes to polyacrylamide gels derivitized with $N$-acetyl glucosamine. J Biol Chem 255:7940-7951.

Scott SA, Davies AM (1990) Inhibition of protein synthesis prevents cell death in sensory and parasympathetic neurons deprived of neurotrophic factor in vitro. J Neurobiol 21:630-638.

Slivka A, Mytilineou C, Cohen G (1987) Histochemical evaluation of glutathione in brain. Brain Res 409:275-284.

Smith PK, Krohn RI, Hermonson GT, Mallin AK, Gortner FH, Prosenzano MD, Fujimoto EK, Goche NM, Olson BJ, Klenk DC (1985) Measurement of protein using the bicinchoninic acid. Anal Biochem 150:76-85.

Steward O (1986) Protein synthesis under dendritic spine synapses during lesion-induced synaptogenesis: evidence for regulation of reinnervation by the target cell. Exp Brain Res [Suppl] 13:173-188.

Thilmann R, Xie Y, Kleihues P, Kiessling M (1986) Persistent inhibition of protein synthesis precedes delayed neuronal death in postischemic gerbil hippocampus. Acta Neuropathol (Berl) 71:88-93.

Tietze $\Gamma$ (1969) Enzymatic method for quantitative determination of nanogram amounts of total and oxidized glutathione: applications to mammalian blood and other tissues. Anal Biochem 27:502-522.

Tsen CC, Tappel AL (1958) Catalytic oxidation of glutathione and other sulfhydryl compounds by selenite. J Biol Chem 233:1230-1237.

Vornov JJ, Coyle JT (1991) Glutamate neurotoxicity and the inhibition of protein synthesis in the hippocampal slice. J Neurochem 56:996-1006.

Weiner HL, Hashim A, Lajtha A (1988) (-)2-Oxo-4 thiazolidine carboxylic acid attenuates 1-methyl-4-phenyl-1,2,3,6-tetrahydropyridine-induced neurotoxicity. Res Commun Substance Abuse 9:53-60.

Wyllie AH (1980) Glucocorticoid-induced thymocyte apoptosis is associated with endogenous endonuclease activation. Nature 284:555557. 